\title{
Building Solidarities through Public Education: National, Multicultural and Cosmopolitan?
}

\author{
Will Kymlicka (Queen’s University Kingston)
}

\begin{abstract}
:
In most countries, the education system seeks to instill two kinds of solidarity: a thick sense of national solidarity with one's co-citizens, and a thinner sense of global solidarity with all of humanity. Many commentators argue that we need to rebalance these two forms of solidarity, de-emphasizing national solidarity and re-centering global solidarities. More radical commentators argue that we should abandon ideas of national solidarity entirely as inherently exclusionary and outdated. I will suggest that we in fact need both kinds of solidarity, although our conception of education for national solidarity needs to reflect our multicultural realities.
\end{abstract}

Keywords:

citizenship education; cosmopolitanism; human rights; migration; multiculturalism; nationalism; solidarity

Solidarities: National, Multicultural and Cosmopolitan ${ }^{1}$

Public education has historically promoted two forms of solidarity: (1) a bounded national solidarity, often tied to ideas of being a "good citizen" of the nation-state, and to associated ideas of loyalty and patriotism; and (2) an unbounded global solidarity, often tied to ideas of universal human rights, and to associated ideas of respect for shared humanity and human dignity. Other levels of solidarity inbetween the nation and the globe have sometimes also played a role in education, most obviously in recent efforts to promote solidarity within the $\mathrm{EU}^{2}{ }^{2}$ but also in earlier efforts to promote pan-Africanism or pan-Arabism. However, in general, debates about solidarity have typically revolved around the dialectic between national and global solidarities.

For many commentators in these debates, there has been a fundamental imbalance in the significance accorded to the two levels of solidarity. National education systems have prioritized national solidarity as a political imperative, while treating global solidarity as a largely symbolic afterthought. Moreover, national solidarity has often been defined in narrow and assimilationist ways, defining the nation in terms of the majority's language, race, religion and culture, while ignoring or stigmatizing minorities. Traditional conceptions of national solidarity are therefore seen as both occluding our obligations to the world outside our national borders and creating injustice to minorities within those borders.

For these and other reasons, it is now widely agreed that traditional conceptions of national solidarity, and the models of citizenship education based on them, are inadequate to the realities of diverse 21 st century classrooms and societies, and to the challenges of an increasingly mobile and interdependent world. However, there remains a deep disagreement about whether our aim is to rehabilitate national solidarity, so that it can continue to play a legitimate role alongside global solidarity, or whether the very idea of national solidarity is irredeemably flawed and obsolete.

In this short paper, I want to make a case for retaining a role for national solidarity, albeit in a significantly revised form, and more generally, for retaining the idea that public education should promote both national and global solidarities. I cannot respond to all of the worries people have about national solidarity, but I will focus in particular on the challenge raised by global mobility. Traditional ideas of national solidarity were defined for a more sedentary world and are often steeped in narratives about how national citizens are "rooted" in particular national homelands. ${ }^{3}$ Do these ideas make any sense in a world on the move?

This is a complicated question, in part because different modes of migration have different relations to national citizenship. Some migrants become citizens: they are able to naturalize and thereby gain rights of membership in the political community where they reside. In traditional countries of immigration, there is a relatively clear path for some immigrants to become citizens. These immigrants are admitted as permanent residents, and having made their life in a new country, they have a right to naturalize after a period of residency (e.g., 5 years), and thereby be included in "the people" in whose name the state governs. ${ }^{4}$

The challenge to ideas of national solidarity in this context seems clear: we need to revise inherited conceptions 
of "the nation" or "the people" to recognize the full diversity of all those who are members of society. Conceptions of "the people" have historically been tied to exclusionary and homogenizing narratives of nationhood, privileging majority ways of belonging while denigrating or rendering invisible minority identities and contributions. A central task of citizenship education is to replace older exclusionary ideas of nationhood with a more inclusive conception which challenges inherited hierarchies of belonging, and which insists that society belongs to all its members, minority as much as majority. All members have a right to shape society's future, without having to deny or hide their identities. Minorities, on this view, including minorities formed through the permanent settlement of immigrants, are not "guests", "visitors", "aliens" or "foreigners", but are "members" and "citizens".

This has been a long-standing goal of multicultural education, to create a more multicultural conception of nationhood and national belonging. Multicultural education has been subject to waves of enthusiasm and skepticism, and I'll return to the skepticism below. But it's worth emphasizing that multicultural education - at least on this traditional understanding - rests on the assumption that immigrants settle permanently, and thereby qualify as "members" of "the people". Contemporary states are grounded in ideas of popular sovereignty: it is "the people" who are the bearers of sovereignty, which they exercise through the state, and permanently-settled immigrants should be seen as members of the people in this sense. Multicultural citizenship education tells us to acknowledge the diversity of the members of our society, but this is tied to the assumption that immigrants have indeed settled for long enough to pass the relevant threshold of membership, transitioning from being visitors to being members.

This is not necessarily true of temporary migrants. Most people do not think that tourists, international students, business visitors, or seasonal workers necessarily have a legitimate claim to political membership. Tourists who visit for one month, or international students who come to study the local language for six months, do not typically have a right to naturalize, or to vote in elections. They are indeed more like "guests" or "visitors" than "members" or "citizens".

Moreover, temporary migrants often do not wish to be treated as members or citizens, insofar as "membership" often entails obligations as well as benefits. Members may be subject to both formal legal obligations (e.g., jury duty) as well as informal social expectations (e.g., to become competent and informed about national politics). As Ottonelli and Torresi note, these formal and informal obligations may not be desired or welcomed by temporary workers. Given their "temporary migration projects", they may prefer to be seen as visitors, and may not wish to be recruited involuntarily into the obligations and expectations of national solidarity (Ottonelli \& Torresi, 2012).
Temporary migrants therefore do not "fit" within most accounts of national belonging, even within explicitly multicultural accounts of nationhood. This is clear in the multiculturalism policies adopted in Canada and Australia, which restrict their programming to citizens or permanent residents, and which exclude temporary workers (such as the seasonal agricultural workers who come to Canada from Mexico at harvest time). Since these groups are not citizens, and are not eligible to become citizens, they are not seen as members of the multicultural Canadian nation. ${ }^{5}$

To say that temporary migrants are excluded from multicultural national citizenship is not to say that they lack claims of justice. They may be visitors not members, but they are human beings, and as such have claims based on their shared humanity. And this of course raises the second level of solidarity I noted earlier, based on universal humanitarianism rather than bounded national solidarity. Whether or not someone is a member of the nation, we must always respect their shared humanity, and avoid treating them in ways that are dehumanizing or degrading. We cannot enslave visitors, subject them to torture or to degrading work, or treat them in ways that violate their human dignity. This second level of cosmopolitan solidarity is often expressed through the idiom of universal human rights, owed to all individuals in virtue of their intrinsic moral status, and one of the central tasks of education is to inculcate respect for human rights and human dignity. Given the rapid rise in various forms of temporary, circular, forced and irregular migration, it is more important than ever that students learn to respect the basic human rights of all people, including the temporary visitors in their midst, the asylum-seekers at the border, and the displaced and oppressed half-way around the world.

So we might think of civics education in an age of migration as having two strands. First, there is citizenship education in the narrow sense, which focuses on how members of the people exercise their popular sovereignty. This requires some account of how a society determines who qualifies for membership, including how long-settled immigrants become members, and I would argue that requires a distinctly multicultural conception of national belonging. Second, there is human rights education, which focuses on an ethics of respect for human dignity, and which is inherently cosmopolitan, applicable whether or not the person is a member of our society, no matter how temporary their stay, or indeed whether they are present in the country or not.

This combination of (multicultural) national solidarity and (humanitarian) global solidarity can be found in accounts of civics education around the world. From Cambodia to Canada, many educators seek to both expand our conception of national membership to acknowledge all those who have settled permanently and made their life in the country (i.e., we need a multicultural ethic of political membership); and simultaneously to strengthen respect for the human rights of 
all, even those who are just temporarily resident or whose rights are at risk in neighbouring or distant countries (i.e., we need a cosmopolitan ethic of human rights). ${ }^{6}$

While both strands are present in many countries, enthusiasm for the multicultural citizenship strand has waned. There are several factors that explain this. One is skepticism about whether national narratives of membership can ever be truly transformed in a multicultural direction. In several countries, earlier moments of openness to multiculturalism seem to have closed, and more homogenizing national narratives have been reasserted (e.g., in France, the UK, Germany). So an earlier enthusiasm about the possibility of generating a compelling multicultural conception of nationhood has faded. ${ }^{7}$ This pessimism seems particularly acute in the Old World countries of Europe, with their deeply embedded national identities, and some commentators have speculated that multiculturalism only works in New World countries founded as "nations of immigrants".

I do not share this pessimism. Embracing multicultural conceptions of nationhood may be difficult in the Old World, but it was difficult in the New World as well. Canada today may be seen as a beacon of multiculturalism, but until the 1960s, it defined itself as a British settler society, and had racially discriminatory immigration policies and assimilationist education policies designed to maintain this self-identity. The shift towards a multicultural national identity was deeply contested and was by no means predestined to succeed (Adams, 2007). And I would suggest that, notwithstanding fashionable talk of the "death" and "retreat" of multiculturalism in Europe, there are comparable examples of a steady shift toward multicultural nationhood. ${ }^{8}$

However, even if multicultural citizenship is politically feasible, it faces a second challenge. Global migration has changed in a way that makes it more difficult to distinguish "permanent" migrants owed multicultural citizenship from "temporary" migrants owed cosmopolitan human rights. The very distinction between permanent and temporary migration is being challenged by scholars who argue that we are living in a world of "super-diversity" with a multitude of legal statuses that are neither wholly temporary nor wholly permanent, but rather have varying degrees and levels of conditionality and precariousness (Vertovec, 2007). This is reflected in calls to replace the old term "age of migration" with the new term "age of mobility". People no longer migrate permanently from country $\mathrm{X}$ to country $\mathrm{Y}$; rather, they move repeatedly. They may become domiciled, but do not "settle". And one of the consequences of super-diversity, commentators argue, is that a multicultural conception of national citizenship is increasingly obsolete (Fleras, 2015). People can no longer be neatly divided into permanent "members" and temporary "visitors": we are all just human beings who find ourselves in a particular place at a particular moment, all subject to risks of dislocation to global economic and environmental trends, all in various states of mobility.
Both of these observations challenge the view that the best response to global migration is to combine multicultural national citizenship (for members) with universal human rights (for non-members). If multicultural citizenship requires being able to identify which newcomers have settled permanently and thereby become members, then the proliferation of conditional legal statuses, and the realities of circular and temporary mobility, mean that fewer newcomers will secure the protections of citizenship. And even those fortunate few who secure legal citizenship may find that they only achieve a second-class citizenship, constantly at risk of being judged alien or inadequate according to exclusionary narratives of nationhood.

Given these trends, skepticism about multicultural citizenship is understandable. But what is the alternative? One option is to give more weight to cosmopolitan human rights, and to reduce the importance of membership rights. States may continue to restrict national citizenship to those newcomers who permanently settle, but we can try to minimize the political significance of this membership status. Even if migrant labourers are not eligible for national citizenship in, say, Austria, this should not affect their labour rights, their health care, or the education rights of their children. These should be seen as fundamental human rights, regardless of membership status. In this way, we can shrink the importance of national citizenship, and expand the importance of universal human rights. The goal is not to expand the Austrian state's view of who is a member of the Austrian nation or people, as the multicultural citizenship approach would seek, but rather to insist that national membership should not determine people's treatment across a range of important issues. The goal is not necessarily to enable them to become citizens, but rather to strengthen the rights they are owed as human beings - in effect, to reduce the price that non-members pay for their lack of political membership.

A more radical suggestion would be to get rid of ideas of membership entirely, and to base civics education entirely on universal human rights. On this proposal, we would only recognize universal rights owed to human beings as such, without any attempt to distinguish members from nonmembers. We would not ask Austrian children to think about their obligations to non-members; nor would we encourage them to have a more multicultural conception of membership in the Austrian nation: rather, we would encourage them not to think in terms of membership at all.

This pure cosmopolitan is a powerful strand in contemporary political theory, precisely because of growing skepticism that multicultural citizenship can respond to the intransigencies of nationalism or the realities of global mobility. And so it is worth asking, can cosmopolitan human rights education take the place of multicultural citizenship education? Can we do without a politics of national solidarity grounded in membership and belonging, and rely instead on 
a cosmopolitan solidarity grounded in respect for our shared humanity?

There are both pragmatic and principled objections to pure cosmopolitanism. Pragmatically, if it is difficult to ask national majorities to embrace inclusive conceptions of national membership, it seems utopian to ask them to stop caring about membership at all. There are also pragmatic worries about political stability. A cosmopolitan commitment to universal human rights tells us nothing about where political boundaries should be drawn. The Universal Declaration of Human Rights provides no guidance on whether there should be 2 countries in the world, or 20 , or 2000, or where their internal and external boundaries should be drawn. A cosmopolitan might respond that any such boundaries should be seen as arbitrary, but it's not clear that a democracy can function if its members view their boundaries this way. A stable democratic community requires that people have a sense of belonging together. For example, Norwegians feel that it is right and proper that they form a single political community which governs its members and its national territory, and that it would be wrong and unjust if Norwegians were subdivided or annexed. If the residents of Norway did not have this sense of belonging together - if they felt that they were just a random group of individuals thrown together in a randomly-drawn territory there would likely be interminable disputes about jurisdiction and boundaries.

And this in turn raises principled questions about whether "nations" or "peoples" have rights to self-determination and territorial sovereignty. Cosmopolitans tend to be dismissive of ideas of rights of self-government, but I would argue it is perfectly legitimate for the Norwegians - or the Navajo- to think of themselves as peoples with rights to self- determination, including the right to govern themselves and their national homelands, which in turn includes the right to make choices about various streams of permanent and temporary migration. ${ }^{9}$ If so, then we are inevitably back to ideas of membership, and to distinguishing those settled immigrants who are owed membership rights from those visitors who are owed universal human rights.

This suggests that human rights education and cosmopolitan solidarity cannot bear all the weight of civics education. Around the world, two distinct problems continually arise: some permanently-settled groups are wrongly denied their membership rights because they do not fit into the received national narrative; and other temporarilysettled immigrant groups are denied their basic human rights. Cosmopolitan human rights education addresses the latter but not the former. Educating students to respect the basic rights of all people, regardless of their membership status, is a fundamental task. But so long as democratic politics is tied up with ideas of membership and belonging, then we also need to educate students to think about membership in an ethically responsible way, including how to critically evaluate the traditional criteria by which membership has been recognized.

This was - and remains - a central task of multicultural citizenship education. The task is not to transcend or evade the distinction between members and non-members, but to think in a critical and ethically responsible way about the diversity of people that belong to society, and the diversity of ways in which they legitimately express that belonging. ${ }^{10}$ Multicultural citizenship education has run into headwinds, but I would argue that it remains an essential part of civics education, alongside calls for more cosmopolitan human rights education.

\section{References}

Adams, M. (2007). Unlikely utopia: The surprising triumph of Canadian pluralism. Penguin.

Antonsich, M., \& Petrillo, E. R. (2019). Ethno-cultural diversity and the limits of the inclusive nation. Identities, 26(6), 706724. https://doi.org/10.1080/1070289X.2018.1494968

Banks, J. A. (Ed.) (2017). Citizenship education and global migration: Implications for theory, research, and teaching. American Educational Research Association. https://doi.org/10.1111/aeq.12271

Bauböck, R, \& Joppke, C. (Eds.) (2010). How liberal are citizenship tests? Robert Schuman Centre for Advanced Studies, EUI Working Paper RSCAS2010/41.

Carens, J. (2013). The ethics of immigration. Oxford University Press.

Fleras, A. (2015). Beyond multiculturalism. In S. Guo \& L. Wong (Eds.), Revisiting multiculturalism in Canada (pp. 311334). Sense. https://doi.org/10.1007/978-94-6300-208-0_19

Lawrence, B., \& Dua, E. (2005). Decolonizing antiracism. Social Justice, 32(4), 120-43.

Kymlicka, W. (2013). Multiculturalism: Success, failure, and the future. Transatlantic Council on Migration.

Kymlicka, W. (2015). Solidarity in diverse societies: Beyond neoliberal multiculturalism and welfare chauvinism. Comparative Migration Studies, 3(1), 1-19. https://doi.org/10.1186/s40878-015-0017-4 
Kymlicka, W. (2017). Multiculturalism without citizenship? In A. Triandafyllidou (Ed.), Multicultural governance in a mobile world (pp. 139-161). Edinburgh University Press.

Kymlicka, W. (2019). Civics education in an age of mobility. In E. Huynh (Ed.), The future of education (pp. 10-14). Institute for Public Policy Research.

Kymlicka, W. (2021). Nationhood, multiculturalism and the ethics of membership. In L. Orgad \& R. Koopmans (Eds.), Majorities, minorities and the future of nationhood. Cambridge University Press (in press).

Ottonelli, V., \& Torresi, T. (2012). Inclusivist egalitarian liberalism and temporary migration. Journal of Political Philosophy, 20(2), 202-224. https://doi.org/10.1111/j.1467-9760.2010.00380.x

Rawls, J. (1985). Justice as fairness: Political not metaphysical. Philosophy and Public Affairs, 14, $223-251$.

Teo, T.-A. (2021). Multiculturalism beyond citizenship: The inclusion of non-citizens. Ethnicities (early view).

Vertovec, S. (2007). Super-diversity and its implications. Ethnic and racial studies, 30(6), 1024-1054. https://doi.org/10.1080/01419870701599465

\section{Recommended Citation}

Kymlicka, W. (2021). Building solidarities through public education: National, multicultural and cosmopolitan? On Education. Journal for Research and Debate, 4(10). https://doi.org/10.17899/on_ed.2021.10.3

\footnotetext{
About the Author

Will Kymlicka is the Canada Research Chair in Political Philosophy at Queen's University in Kingston, Canada. He is the coeditor of The Strains of Commitment: The Political Sources of Solidarity in Diverse Societies (OUP, 2017), and co-director, with Irene Bloemraad, of a new program on Boundaries, Membership and Belonging, funded by the Canadian Institute for Advanced Research.

${ }^{1}$ This paper draws upon an analysis I prepared for the "Future of Education" project of the Institute for Public Policy Research (Kymlicka, 2019).

${ }^{2}$ See, for example, the European Solidarity Corps, managed by the European Commission, and aimed at youth between the ages of 18 and 30

(https://europa.eu/youth/solidarity_en).

${ }^{3}$ To take just one example from my field of political philosophy, John Rawls suggested that when theorizing social justice, we should begin with a picture of society "as a more or less complete and self-sufficient scheme of cooperation, making room within itself for all the necessities and activities of life, from birth until death. ... [C]itizens do not join society voluntarily but are born into it, where, for our aims here, we assume they are to lead their lives" (Rawls, 1985, p. 233). Migration, for Rawls, was seen as an exception, and the principles for managing migration are to be sorted out after first defining principles of justice for the "normal" case of sedentary citizens for whom "all the necessities and activities of life from birth to death" occur within national boundaries.

${ }^{4}$ For the idea that political citizenship should track social membership, and why this entails that long-settled immigrants have a right to naturalize, see Carens (2013). Carens argues that length of residency should be a sufficient condition for a right to naturalize, and opposes further conditions, such as language tests or employment status. For a good overview of these debates, see Joppke and Baubock (2010).

${ }^{5}$ For a defense of this traditional linking of multiculturalism to national citizenship, see Kymlicka (2017). For a critique, see Teo (2021).

${ }^{6}$ For an overview of citizenship education around the world illustrating these dimensions, see Banks (2017).

${ }^{7}$ See Antonsich and Petrillo (2019) for an interesting discussion of the Italian case.

${ }^{8}$ See Kymlicka (2013) on the resilience of multiculturalism in many European countries.

${ }^{9}$ Lawrence and Dua (2005) argue that cosmopolitan defenses of migrants' rights to freely settle anywhere ignore indigenous rights to govern themselves and their territories.

${ }^{10}$ For some reflections on a new ethic of membership which recognizes diverse ways of belonging and participating, see Kymlicka (2015, 2021).
} 